April 2015

\title{
Everything, Nothing, Harvey Keitel: A Review
}

Sarah Geis

Third Coast International Audio Festival

Follow this and additional works at: http://ro.uow.edu.au/rdr

Part of the Audio Arts and Acoustics Commons, Other Film and Media Studies Commons, and the Radio Commons

\section{Recommended Citation}

Geis, Sarah, Everything, Nothing, Harvey Keitel: A Review, RadioDoc Review, 2(1), 2015.

doi:10.14453/rdr.v2i1.6

Research Online is the open access institutional repository for the University of Wollongong. For further information contact the UOW Library: research-pubs@uow.edu.au 


\title{
Everything, Nothing, Harvey Keitel: A Review
}

\begin{abstract}
Although producer Pejk Malinowski is originally from Denmark, and Everything, Nothing, Harvey Keitel is a project of London-based Falling Tree Productions, its premise seems cringingly American: our narrator goes to a self-help class, has an encounter with a celebrity. Which is to say, the risk of self-indulgence is high. To make it worse: the documentary takes place almost entirely within Malinovski's mind. But these factors make it only more astonishing to hear how - through his singular voice, playful sense of humour, and impeccable sound design - Malinovski tells a story that makes the listener laugh, feel, and consider the intertwined nature of storytelling and happiness.

Everything, Nothing received highest honours at the inaugural In The Dark/Sheffield International Documentary Competition, as well as Best Radio Drama in both the 2014 Prix Europa Competition and 2015 BBC Audio Drama Awards.
\end{abstract}

\section{Keywords}

radio documentary, audio feature, Harvey Keitel, meditation 


\title{
Everything, Nothing, Harvey Keitel: A Review
}

\section{Reviewer: Sarah Geis}

\author{
Producer: Pejk Malinowski
}

Falling Tree Productions, 2013

First broadcast on Between The Ears, BBC Radio 3, 2013)

Duration: 18' 19"

Audio here:

https://soundcloud.com/fallingtreeproductions/shadowplay-slowmovement-everything-nothing-harvey-keitel

A few years ago, after a break-up, I enrolled in a meditation course held at a local church. The class was taught by a modern renunciate who was drop dead gorgeous, a mini-Cate Blanchett with glowing skin and an easy laugh. If meditation did this to her, clearly I was on the right track.

At the first session I ran into a man I recognized from my work, Joe, who told me he had also just split with his partner. I spent the first two weeks of class cross-legged, upturned hands resting on my knees, picturing our future together - our bilingual children, how we would tell the story of our meeting, our garden. We later became friendly and I learned that he was a) gay, b) Republican, and c) didn't like vegetables.

Which is just to say, our minds at rest have a tendency invent elaborate (and, often, mundane) fictions. Buddhists call this the monkey mind, the memories, anxieties, and snippets of dialogue that clamour and chatter and pop up, one after another - trying to make meaning whether there is meaning to be made, or not.

In Everything, Nothing, Harvey Keitel, poet and producer Pejk Malinovski chronicles his attempt to tame these monkeys through meditation:

Pejk Malinovski: Why do I meditate? I meditate to rein in that constant flow of thoughts. That voice in my head that keeps on yammering and constant commentary, like some kind of 
embedded reporter. Did I say something wrong at dinner last night? I should really buy an apartment, I'm getting too old to sublet. Did that girl notice me looking at her breasts? Have I been wearing these pants too long?

Pejk Malinovski (overlay, panning left and right): Blah, blah, blah, blah, blah, blah, blah.

Malinovski is originally from Denmark, and Everything, Nothing is a project of London-based Falling Tree Productions. Even so, the premise seems cringingly American: our narrator goes to a self-help class, has an encounter with a celebrity. Which is to say, the risk of self-indulgence is high. To make it worse: the documentary takes place almost entirely within Malinovski's mind. But these factors make it only more astonishing to hear how - through his singular voice, playful sense of humour, and impeccable sound design - Malinovski tells a story that makes the listener laugh, feel, and consider the intertwined nature of storytelling and happiness.

Everything, Nothing begins in a very unusual way for a radio doc - with a billboard, or opening sequence, straight out of a movie preview. A dramatic swell of horns breaks for Malinovski to declare "Everything," then, after a crush of New York City traffic noise, "Nothing," then, after deep meditative breathing, "Harvey Keitel." This opening sets listeners' expectations toward Hollywood - but, from the very start, Malinovski plays with and questions Hollywood storytelling conventions.

Joan Didion famously wrote 'We tell ourselves stories in order to live', and then there's the Buddhist concept of samsara, which posits that the storytelling impulse is, actually, the root of all suffering. Samsara is the cycle of birth, life, and death - and also the mechanism of mind that interprets sensation and turns it to narrative - Malinovski's 'embedded reporter', above. We tell ourselves stories, and then we believe those stories, and then - too often - we torture ourselves with them. Meditation, or 'mindfulness', is one technique to calm this tendency. But the shedding of the narrative impulse is not easy for anyone - let alone a person whose livelihood and identity is as a storyteller. 
Everything, Nothing first aired on BBC Radio 3's Between the Ears, a program devoted to 'adventures in radio'. As an adventure, the documentary is rather... sedentary. In fact, nearly the entire story takes place behind our narrator's closed eyes. You can think of it as a locationbased audio tour, with the mind as our geography. Our narrator sits on a chair, his eyes shut. You can do the same: make yourself comfortable, pace your breath to his breath. The recorder becomes his body, becomes our body.

The first instruction is 'simply hearing', says the meditation instructor, her voice trained to relax, her sensible-sounding shoes, perhaps, shuffling on the concrete floor. 'Simply listen to the sounds around you.' We hear a siren, gradually growing distant. Creak of chairs, fidgeting of hands on denim, a metallic rustling - maybe someone has dropped their keys? Then there is the tone of the room, some sort of ventilation system. Like Malinovski's protagonist, the listener works to cobble a story from the input, but is encouraged to listen in a mode outside that of producer/critic:

Meditation instructor: We begin with hearing because it points to some of the natural qualities of mindfulness... We don't need to define the sounds as being a certain thing... We don't need to manipulate them... We don't have to do anything about them in order to hear them. Simply listen.

Here lies the central problem of Everything, Nothing. How do we refrain from doing anything about the sensations around us? The goal is to listen as a passive exercise, versus an exercise in interpretation. In a recent interview for the podcast Tape, Malinovski said:

When I make a structure it's not a traditional Hollywood storyline where there's a beginning, a middle, and an end and conflict and resolution. It's more about tension and release. I think it's more about composing music, actually.

But Malinovski is also aware that resisting this ordering impulse is near impossible for a storyteller. In the same Tape interview, he notes that when one works in radio, one works in time, and therefore, unavoidably, 'something comes before something else' (Tape, episode 14) and a storyline is created. 
In Everything, Nothing it is through the sound of a cough (then a quick peek to confirm) that Malinovski discovers he is sitting next to the actor Harvey Keitel, who, it seems fair to say, represents a very traditional Hollywood storyline; he is known for his work in thrillers and crime dramas, playing mobsters, hit men, and corrupt police officers. In fact, Keitel specializes in, that narrative necessity, endings: Judas in The Last Temptation of Christ, a murderer in Taxi Driver, 'clean-up' experts in both Pulp Fiction and Point of No Return, tasked with erasing all traces of a murder from a crime scene.

Understandably, Malinovski is distracted by the realization of his neighbour's identity:

Pejk Malinovski: Immediately, I started thinking about all the things Harvey Keitel might be thinking about... Or, I was trying to think about all the things that Harvey Keitel was trying not to think about.

The remainder of the documentary, layered over Malinovski's closely recorded deep-breathing, is a clever interplay between the meditation instructor's guidance, Malinovski's inner commentary, and scenes from Harvey Keitel's oeuvre.

Pejk Malinovski: Harvey Keitel, a physical reality in the chair next to me, but also an idea in my mind. My idea of Harvey Keitel projected onto the chair next to me. And my memory of all the parts he's ever played. Like the corrupt police officer in Bad Lieutenant.

Harvey Keitel: [howls]

Meditation instructor: And then bring that same feeling tone that quality of relaxed, open, spacious awareness - to feeling the breath. Take a few deep breaths. And release it.

Pejk Malinovski: It was shocking to see such a famous face. The face of so many mean and ill adjusted gangsters looking so peaceful and withdrawn. His large hands folded in his lap. Our intimacy made me feel protective of him. Like I was in on a secret. The secret of who he was. 
Harvey Keitel: [howl]

Pejk Malinovski: And inside that secret was the cocaine-sniffing lieutenant howling for forgiveness.

Harvey Keitel: [howl]

Pejk Malinovski: He lost all his money gambling and now he's in the church.

Harvey Keitel: [wailing] What am I gonna do?

Pejk Malinovski: God is his last hope. Or maybe he's here to file a complaint.

Harvey Keitel: [shouting] Where were you? Where were you?

Unable to resist doing something about these memories arising, Malinovski interjects to influence - and subvert - the narrative. To differentiate this dreamy 'in-scene' persona from meditation class narrator, Malinovski adds reverb to his voice, seamlessly mixing the new dialogue over the original film scores:

Pejk Malinovski: I'm here now. I'm right here.

Harvey Keitel: [howls]

Pejk Malinovski: Come, take my hand. Stand up. It's cold on that stone floor.

Harvey Keitel: [howls]

Pejk Malinovski: You can sit here in this pew.

Harvey Keitel: [wailing] I tried to do the right thing, but I'm weak.

Pejk Malinovski: It's ok to cry. Even when you're a grown man. 
Meditation instructor: Then allow your breath to become natural. You don't have to try to make it deeper or different. Just be with it, the way that it is. And the way that it changes.

Harvey Keitel: [wailing] Why didn't you help me?

Mediation Instructor: See if you can feel just one breath. Just this one.

The contrast between the meditation instructor's calm and the anguish of Keitel's lieutenant begging for forgiveness is very funny. But the repeated joke of the howl also becomes tedious, in the way that obsessive thoughts do.

Is the whole piece an inside joke for meditators? I don't think so. Everything, Nothing received highest honours at the inaugural In The Dark/Sheffield International Documentary Competition, as well as Best Radio Drama in both the 2014 Prix Europa Competition and 2015 BBC Audio Drama Awards. ${ }^{1}$ It's hard to believe that all of those judges and jurors are in on some kind of New Age punchline, patchouli incense burning in the corner as they exit to take their smoke breaks. No, the story speaks to something broader than that - it's a close-up look into the workings of the mind, specifically under the influence of celebrity.

For the remainder of Everything, Nothing Malinovski continues to interweave his present-tense attempt at meditation with scenes from Harvey Keitel's movies, in which Malinovski intervenes to extract Zenlike lessons. In one particularly strong sonic transition, the pronounced breathing of meditation turns to heavy breathing mixed with cocktail

\footnotetext{
${ }^{1}$ Which begs the question: is Everything, Nothing drama or documentary? In his review of Malinovski's Poetry, Texas, Sean Street explores Malinovski's poetic genres-crossing, concluding that 'seeking to define things too carefully and academically, divorced from the spirit of the making, can be an arid, specious activity' and introducing the term 'impressionistic radio' (Street, RDR). That said, Everything Nothing is both based in fact and scripted - satisfying In The Dark/Sheffield's definition of documentary as 'self-contained audio work with a factual basis' as well as well as veering into dramatic territory. Perhaps 'feature' is the best categorisation, with its task and 'destiny', according to former BBC Features head Lawrence Gilliam, being 'to mirror the true inwardness of its subject' (quoted in Hall, 96).
} 
party chatter from the film Holy Smoke, as Malinovski imagines Keitel having an affair:

Pejk Malinovski: He's SO famous, what's he even doing here? I bet he has invitations for five different cocktail parties - you know, the good ones, where the waiters wear white gloves and there's just the right balance of celebrities and not-yet celebrities. And the beautiful young actress in the red dress would chat him up, and soon she would drag him out onto the darkened terrace.

Harvey Keitel: Take it easy.

Pejk Malinovski: She would take his big hand and place it on her breast. And beg him to come home with her.

Harvey Keitel: Keep breathing.

Pejk Malinovski: And they would make out a little.

Harvey Keitel: Keep breathing. Down here.

Meditation instructor: See if you can let go whatever's taking your attention.

Beautiful young actress in red dress: Do you have a website?

Meditation Instructor: Bring it back to the feeling of the breath.

Pejk Malinovski: Oh wait he's probably married. Well I guess he could still have an affair.

Harvey Keitel: Keep breathing.

Pejk Malinovski: I didn't mean to get him into trouble. I was just thinking that he would have plenty of opportunities to get into trouble.

Here Malinovski demonstrates how our fictions and feelings are deeply intertwined; he creates a purely fictional scenario in his mind (Keitel's affair) and then feels genuinely bad that he 'got] him in trouble'. 
The documentary ends with a back-and-forth between Malinovski and Keitel's character from Lulu on the Bridge (a jazz musician-cum-murder suspect):

Pejk Malinovski: Harvey Keitel, are you a cloud or are you the sky?

Harvey Keitel: [laughs] What?

Pejk Malinovski: C'mon, it's a game. I've given up on my breath. You have to answer. Here's another one. Are you an ocean or a river?

Harvey Keitel: An ocean or a river? A river.

Pejk Malinovski: Are you a match or a cigarette lighter?

Harvey Keitel: Match. Definitely a match.

Pejk Malinovski: Are you a car or a bicycle

Harvey Keitel: Bicycle.

Pejk Malinovski: Are you an owl or a hummingbird?

Harvey Keitel: Hmm. I used to be a hummingbird but now I'm an owl.

Pejk: Sneakers or boots?

Harvey Keitel: Boots. Now it is my turn.

Pejk: Wait, no, I just got started.

Harvey: Concentrate now. Are you a real person or a spirit?

Pejk Malinovski: I think I'm a real person but I'm confused. I'm having an out of body kind of experience.

Harvey Keitel: Do you understand what's happened or are you in the dark like me? 
Pejk Malinovski: I think I'm in the dark like you.

This sequence transforms to resemble a series of koans, 'paradox[es] to be meditated upon that [are] used to train Zen Buddhist monks to abandon ultimate dependence on reason and to force them into gaining sudden intuitive enlightenment', according to Merriam-Webster. Here, finally, Malinovski and Keitel agree to suspend 'understand[ing] what's happened' in favour of just noticing the darkness.

As I delayed writing this essay, I found myself watching Beyoncé videos on You Tube. In the video for 'Pretty Hurts', Beyoncé is a contestant in a beauty pageant, wearing a low-cut sequined gown and a white sash that reads 'Miss Third Ward'. And then the pageant's host comes onstage, an older man in a silver lamé suit jacket. A familiar, whispery, voice. Is it? Could it be?

Harvey Keitel: You've done a great job in the competition so far. Harvey! What's he doing here? The music pauses.

Harvey Keitel: Miss Third Ward, your first question: What is your aspiration in life?

Beyoncé: Oh my aspiration in life? Wow. That's a great question. I wasn't expecting that question... What is my aspiration in life?

[long pause, cut to images of Beyoncé drowning, crying, head in hands]

Beyoncé: Um. Well. My aspiration in life would be... to be happy.

What does this mean? Is Harvey Keitel some kind of happiness doula, showing up in radio stories and music videos, delivering us out of the rat race and toward our one true self?

Maybe. 
More likely I'm just trying to make some meaning, to connect the dots. Here I am, bringing Harvey Keitel into the scene as some kind of crime scene 'clean-up' man once again, to pick up the pieces.

\section{REFERENCES:}

Hall, Alan (2010). "Cigarettes and Dance Steps." In Biewen, J and Dilworth A. Reality Radio. UNC Press. pp.96-107.

In The Dark/Sheffield Audio Award. Rules and regulations:

www.inthedarkradio.org/award/rules-and-regulations/

Street, Sean, "Poetry, Texas: Review 1", RadioDoc Review, 1(1), 2014. Available at: http://ro.uow.edu.au/rdr/vol1/iss1/4 http://dx.doi.org/10.14453/rdr.v1i1.3

Tape podcast, episode 14: http://taperadio.org 


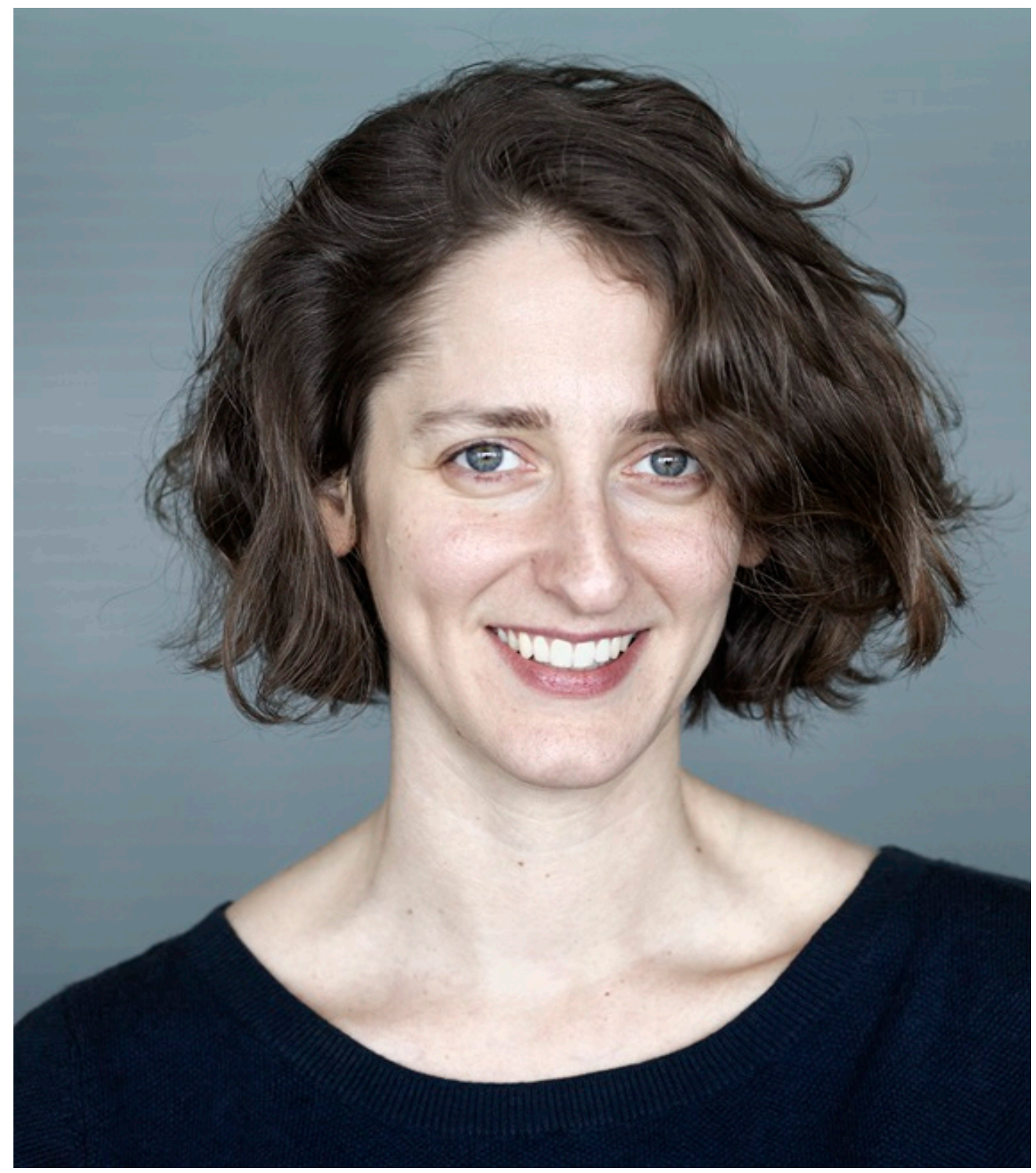

As managing director of the Third Coast Festival, Sarah Geis curates audio stories for the organization's radio show, podcast, and website. She also organizes listening events and producer gatherings in Chicago and beyond. Her documentary career began at StoryCorps, where she spent several years traveling the country in a silver bullet van conducting interviews and leading community outreach efforts. As a producer, her stories have aired on radio stations throughout the United States and a 2014 co-production received first place in the Missouri Review's audio contest. 